CLINICAL STUDY

\title{
Increased reverse triiodothyronine is associated with shorter survival in independently-living elderly: the Alsanut study
}

\author{
E Forestier $^{1,2}$, S Vinzio ${ }^{1,2}$, R Sapin $^{2,3}$, J L Schlienger ${ }^{1,2}$ and B Goichot ${ }^{1,2}$ \\ ${ }^{1}$ Service de Médecine Interne et Nutrition, Hôpital de Hautepierre, Hôpitaux Universitaires de Strasbourg, Avenue Molière, 67098 Strasbourg Cedex, \\ France, ${ }^{2}$ Faculté de Médecine, 4 rue Kirschleger, 67085 Strasbourg Cedex, France and ${ }^{3}$ Laboratoire de Biophysique, ULP/CNRS UMR 7191, Hôpital Civil, \\ 67091 Strasbourg Cedex, France \\ (Correspondence should be addressed to B Goichot; Email: bernard.goichot@chru-strasbourg.fr)
}

\begin{abstract}
Objective: Increased reverse tritiodothyronine $\left(\mathrm{T}_{3}\right)$ used to be described as a part of euthyroid sick syndrome (ESS). It was demonstrated to be associated with increased mortality in acutely ill patients. It can also be found with low or normal $\mathrm{T}_{3}$ in non-severely ill subjects but its significance remains unclear.

Patients and design: The Alsanut study included a representative sample of 440 independently-living subjects aged 65 or over constituted between January 1988 and September 1989. Past and current medical history and nutritional data were collected at inclusion. Baseline thyroid hormone (TSH, $\mathrm{FT}_{4}$, $\mathrm{FT}_{3}$ and $\mathrm{rT}_{3}$ ) serum levels were measured. Life status was determined on 1 December 2005.

Results: Of the 374 elderly subjects included in the final analysis, 52 had abnormal TSH (43 with hyperthyroidism, nine with hypothyroidism) and $80.7 \%$ had died by 1 December 2005 . There was no statistical difference in survival between subjects according to thyroid function $(P=0.54)$. Of the 322 elderly subjects with normal TSH, mortality rate was $81.1 \%$. ESS was found in $3.4 \%$, whereas $8.1 \%$ of the participants displayed elevated $\mathrm{rT}_{3}$ with normal $\mathrm{FT}_{3}$. Time to death was strongly related to $\mathrm{rT}_{3}$ $(P<0.0001)$ and $\mathrm{FT}_{3}(P<0.0001)$ in a univariate analysis. After adjusting for other confounding variables, $\mathrm{rT}_{3}$ was the only thyroid hormone associated with shorter survival $(P=0.014)$.

Conclusions: $\mathrm{RT}_{3}$ was the only thyroid hormone associated with shorter survival in a representative population of independently-living elderly. In these subjects, isolated elevated $\mathrm{rT}_{3}$ might be an equivalent of ESS, reflecting declining health.
\end{abstract}

European Journal of Endocrinology 160 207-214

\section{Introduction}

Acute and severe chronic non-thyroidal illnesses are frequently associated with non-specific disturbances of thyroid function tests called 'euthyroid sick syndrome' (ESS) $(1,2)$. This syndrome is characterized by a constant decrease in tri-iodothyronine $\mathrm{T}_{3}$ and free $\mathrm{T}_{3}$ $\left(\mathrm{FT}_{3}\right)$ serum concentrations. It can be associated with more variable disturbances of the other thyroid parameters, such as an increase in reverse $\mathrm{T}_{3}\left(\mathrm{rT}_{3}\right)$, a decrease in $\mathrm{T}_{4}$ and free $\mathrm{T}_{4}\left(\mathrm{FT}_{4}\right)$, and even a decrease in TSH concentrations in the most severe forms $(3,4)$.

Substantial data suggest that there are probably several kinds of ESS, depending on the type of associated diseases, severity or acute, or chronic form. In acute ESS, it was shown that the decrease in $\mathrm{T}_{3}$ and the increase in $\mathrm{rT}_{3}$ are related to mortality (5-10). In nonacutely ill elderly, $\mathrm{T}_{3}$ and $\mathrm{rT}_{3}$ are often decreased and increased respectively, but many questions remain as to whether these disturbances are due solely to aging or to poor health status $(11,12)$.
Alsanut was an epidemiological study conducted in the late 1980's that aimed at determining the prevalence of thyroid dysfunction and ESS in 440 independently-living elderly (13). It individualized a group of subjects who displayed elevated $\mathrm{rT}_{3}$ with $\mathrm{FT}_{3}$ and TSH within normal ranges. They were characterized by lower energy intake, older age, and lower cholesterol level. Sixteen years later, the mortality data were collected in this population to explore the relationship between baseline clinical and biological characteristics and survival, with a focus on $\mathrm{rT}_{3}$.

\section{Subjects and methods}

\section{Subjects}

The representative sample of independently-living subjects aged 65 or over in Bas-Rhin (northeastern France) who were included in the Alsanut study was constituted as previously published (13). Briefly, subjects were randomized based on electoral lists with 
stratification on age, gender, and settlement (rural versus urban). Deceased persons and those refusing to participate in the study or give a blood sample were replaced by a subject with the same characteristics taken from an additional list. Inclusion in the study was spread over a period of 20 months from January 1988 to September 1989.

A total of 440 subjects accepted to participate in the study. They were subsequently interviewed by an investigator and completed a questionnaire on their medical history (diabetes, cardiac failure, hypertension, cerebrovascular disease, ongoing neoplastic disease), current treatment, smoking status, and mean energy and nutrients intake on a 3-day food record. Body mass index was calculated for each person.

No subject was undergoing corticosteroid therapy. Seven subjects taking amiodarone were excluded from the final analysis, as well as 13 others who were on synthetic thyroid hormones or antithyroid drugs.

\section{Biological data}

For each subject a blood sample was taken in the morning at inclusion. TSH, thyroid hormones (free $\mathrm{T}_{4}$ $\left(\mathrm{FT}_{4}\right)$, free $\mathrm{T}_{3}\left(\mathrm{FT}_{3}\right)$, and reverse $\mathrm{T}_{3}\left(\mathrm{rT}_{3}\right)$ ), total and high density lipoprotein (HDL) cholesterol, and prealbumin serum concentration were measured. TSH and thyroid hormones were assayed using radioimmunological commercial kits (Behringwerke AG, Marburg, Germany for TSH; Amerlex MAB, Kodak diagnostic, UK for $\mathrm{FT}_{4}$; Amerlex M, Kodak diagnostic, UK for $\mathrm{FT}_{3}$; and Biodata, Montecelio, Italy for $\mathrm{rT}_{3}$ ). Normal ranges that had been determined on subjects from various European centres were provided by the manufacturer. They were $0.4-$ $4.5 \mathrm{mU} / \mathrm{l}$ for TSH; $13.2-28.8 \mathrm{nmol} / \mathrm{l}$ for $\mathrm{FT}_{4}$; 3.3$8.22 \mathrm{nmol} / \mathrm{l}$ for $\mathrm{FT}_{3}$; and $0.14-0.53 \mathrm{nmol} / \mathrm{l}$ for $\mathrm{rT}_{3}$. Total cholesterol and HDL cholesterol were assayed using the caloric enzymatic method (CHOP-PAP) on a Hitachi 737 analyser. Normal ranges were 1.25$1.85 \mathrm{~g} / \mathrm{l}$ (males) and 1.35-2.10 g/l (females) for total cholesterol, more than $0.40 \mathrm{~g} / \mathrm{l}$ (males) and more than $0.50 \mathrm{~g} / \mathrm{l}$ (females) for HDL cholesterol, and 220$350 \mathrm{mg} / \mathrm{l}$ (males), and 200-300 mg/l (females) for prealbumin.

Technical problems concerning biological data led to the exclusion of 18 subjects.

\section{Mortality data}

The registry offices of the towns where the subjects were born were consulted to determine if the subjects were living or had died after 1 December 2005. This information was not available for 28 subjects leading to their exclusion from the final analysis. Dates of death were collected but cause of death could not be assessed in this way.

\section{Statistical analysis}

Unless otherwise stated results are expressed as mean \pm s.D. Because of its markedly skewed distribution, TSH was natural-log transformed before analysis. The Pearson's product-moment correlation coefficient was used to evaluate the association among continuous variables. The study population was further divided into three tertiles based on serum $\mathrm{rT}_{3}$ levels. The intergroup comparisons were determined by ANOVA test. Cumulative survival was analyzed using the Kaplan-Meier method, with every continuous variable divided into tertiles. Multivariate survival analyses were performed with a Cox model. They were adjusted first for age and sex, and other major confounding factors (total and high-density lipoprotein cholesterol levels, prealbumin level, systolic and diastolic blood pressure, body mass index, smoking status, pre-existing disease such as diabetes mellitus, ischemic heart disease, cardiac failure, cerebrovascular disease, and cancer) based on literature data or univariate survival analysis $(P<0.05)$ were subsequently added to the multivariate models. The relative strength and interdependence of these relationships were investigated by an automatic backward stepwise selection. Hazard ratios (HRs) with a 95\% confidence interval were used to estimate the relative risk of death. HRs are expressed by a 1-unit increase in the parameter at baseline. Receiver operator characteristic (ROC) curve analyse were carried out for different parameters (age, total cholesterol, HDL cholesterol, prealbumin, TSH, and thyroid hormones) using occurrence of death versus non-occurrence as the outcome measure. All tests were two-sided, and $P<0.05$ was considered statistically significant. Data were analyzed using SPSS 15.0 (SPSS Inc., Chicago, IL, USA).

\section{Results}

\section{Thyroid status and its relationship with mortality}

Of the 374 persons included in the study, 322 had normal TSH levels between 0.4 and $4.5 \mathrm{mU} / \mathrm{l}$. Forty three subjects had TSH levels below $0.4 \mathrm{mU} / \mathrm{l}$ (between 0 and $0.39 \mathrm{mU} / \mathrm{l}$ ) with normal $\mathrm{FT}_{4}$ in 34 subjects corresponding to subclinical hyperthyroidism. TSH was above $4.5 \mathrm{mU} / \mathrm{l}$ in nine subjects (between 5.5 and $45 \mathrm{mU} / \mathrm{l}$ ), with normal $\mathrm{FT}_{4}$ in three of them reaching the criteria for subclinical hypothyroidism. The characteristics of the three groups, defined according to TSH levels, did not differ significantly (data not shown).

On this whole sample, survival was not associated with $\mathrm{FT}_{4}(r=0.007 ; P=0.89)$ and TSH $(r=-0.043$; $P=0.4$ ) levels. Conversely, a significant correlation existed with $\mathrm{rT}_{3}(r=-0.288 ; P<0.001)$ and $\mathrm{FT}_{3}$ levels $(r=0.200 ; P<0.001)$. Kaplan-Meier analysis did not show any significant difference in survival between the three groups defined by TSH levels $(P=0.54)$ or by $\mathrm{FT}_{4}$ 
levels $(P=0.80)$, unlike $\mathrm{FT}_{3}(P<0.001)$ and $\mathrm{rT}_{3}$ $(P<0.001$; data not shown $)$.

\section{Characteristics of euthyroid subjects according to $\mathrm{rT}_{3}$ and $\mathrm{FT}_{3}$ levels}

Three hundred and twenty-two subjects with normal TSH level were included in the following analysis, 168 males and 154 females with a mean age of $76.3 \pm 7.4$ years. Their characteristics are summarized in Table 1. Briefly, 33 (10.2\%) subjects suffered from diabetes and 115 (35.7\%) from hypertension. A history of stroke, cardiac failure, or ischemic heart disease was noted in $21(6.5 \%), 33(10.2 \%)$, and $44(13.7 \%)$ people respectively. Fifteen $(4.7 \%)$ persons had been treated for neoplastic disease, 113 (35.1\%) subjects were active or former smokers.

Mean TSH and $\mathrm{FT}_{4}$ at inclusion were $1.29 \pm$ $0.68 \mathrm{mUI} / \mathrm{l}$ and $20.24 \pm 3.69 \mathrm{nmol} / \mathrm{l}$ respectively. Two hundred and eighty-eight subjects (89.4\%) had normal $\mathrm{FT}_{3}$ and $\mathrm{rT}_{3}$ levels. Eleven (3.4\%) participants had low $\mathrm{FT}_{3}$ (between 1.85 and $3.23 \mathrm{nmol} / \mathrm{l}$ ) corresponding to the definition of ESS, with normal $\mathrm{rT}_{3}$ levels in seven, and $\mathrm{rT}_{3}$ above the normal range (between 0.68 and $1.50 \mathrm{nmol} / \mathrm{l})$ in four. Twenty-six subjects $(8.1 \%)$ had elevated $\mathrm{rT}_{3}$ (between 0.54 and $1.50 \mathrm{nmol} / \mathrm{l}$ ) with normal $\mathrm{FT}_{3}$. The remaining biological data are reported in Table 1.

On 1 December 2005, 261 (81.1\%) subjects had died and $61(18.9 \%)$ were alive. Median survival was $2755 \pm 352$ days $(\sim 7.5 \pm 1.0$ years $)$. It was significantly shorter for participants with isolated elevated
$\mathrm{rT}_{3}$ or low $\mathrm{FT}_{3}$ compared with those with normal hormone levels $(P=0.001)$. Eighteen $(5.6 \%)$ died within 1 year of the inception, $24(7.4 \%)$ between 1 and 2 years, $29(9 \%)$ between 2 and 3 years, 25 $(7.8 \%)$ between 3 and 4 years, and $226(70.2 \%)$ after 4 years or later.

\section{Subject characteristics by $r T_{3}$ tertile}

The population was divided into three tertiles based on $\mathrm{rT}_{3}$ serum concentrations: the lowest tertile, less than $0.31 \mathrm{nmol} / \mathrm{l} \quad(n=104)$; the middle tertile, 0.31 to $0.41 \mathrm{nmol} / \mathrm{l}(n=109)$; and the highest tertile, more than $0.41 \mathrm{nmol} / \mathrm{l}(n=109)$.

The characteristics of these three groups are shown in Table 2. Increasing age and $\mathrm{FT}_{4}$ concentrations were noted throughout the $\mathrm{rT}_{3}$ tertiles, whereas an inverse relationship between energy intake, cholesterol concentrations, prealbuminemia, and $\mathrm{rT}_{3}$ serum levels was found. Ischemic heart disease was more frequently reported by subjects with the highest $\mathrm{rT}_{3}$ levels.

\section{Relation between baseline parameters and survival}

In a Kaplan-Meier analysis, shorter survival was significantly related to increased $\mathrm{rT}_{3} \quad(P<0.0001$; Fig. 1, part A) and decreased $\mathrm{FT}_{3}(P<0.0001$; Fig. 1, part B), whereas there was no relation with TSH and $\mathrm{FT}_{4}(P=0.328$ and 0.169 respectively). Other variables significantly associated with early death in univariate analysis were advanced age $(P<0.0001)$, male gender

Table 1 Characteristics of subjects by reverse triiodothyronine $\left(T_{3}\right)$ and free $T_{3}$ level.

\begin{tabular}{|c|c|c|c|c|c|}
\hline Characteristics & $\begin{array}{l}\text { Total } \\
(n=322)\end{array}$ & $\begin{array}{c}\text { Normal } \mathbf{F T}_{3} \text { and } \mathbf{r T}_{\mathbf{3}} \\
(n=285)\end{array}$ & $\begin{array}{l}\text { Isolated elevated } \mathbf{r T}_{3} \\
\qquad(n=26)\end{array}$ & $\begin{array}{c}\text { Low } \mathbf{F T}_{3} \\
(n=11)\end{array}$ & $P$ value ${ }^{\star}$ \\
\hline Age (years) & $76.3 \pm 7.4$ & $75.8 \pm 7.4$ & $80.1 \pm 6.4$ & $79.4 \pm 6.1$ & 0.007 \\
\hline $\operatorname{Sex}(M / F)$ & $168 / 154$ & $147 / 138$ & $15 / 11^{-}$ & $6 / 5$ & 0.83 \\
\hline Death (\%) & $261(81.1)$ & 225 (78.9) & $25(96.1)$ & $11(100)$ & 0.03 \\
\hline Median time to death (days) & $2755 \pm 352$ & $2918 \pm 407$ & $1036 \pm 210$ & $1348 \pm 550$ & 0.001 \\
\hline BMI $\left(\mathrm{kg} / \mathrm{m}^{2}\right)^{\mathrm{a}}$ & $26.8 \pm 6.1$ & $27.0 \pm 6.3$ & $26.3 \pm 3.7$ & $24.5 \pm 5.6$ & 0.38 \\
\hline Diabetes (\%) & $33(10.2)$ & $31(10.9)$ & $1(3.8)$ & $1(9.1)$ & 0.52 \\
\hline Cancer (\%) & $15(4.7)$ & $14(4.9)$ & $2(7.7)$ & $0(0)$ & 0.59 \\
\hline Cerebrovascular disease & $21(6.5)$ & $14(4.9)$ & $5(19.2)$ & $2(18.2)$ & 0.005 \\
\hline Cardiac failure (\%) & $33(10.2)$ & $23(8.1)$ & $9(34.6)$ & $2(18.2)$ & 0.0001 \\
\hline Ischemic heart disease (\%) & $44(13.7)$ & $37(13.0)$ & 5 (19.2) & $3(27.3)$ & 0.27 \\
\hline Hypertension (\%) & $115(35.7)$ & $97(34.0)$ & $17(65.4)$ & $1(9.1)$ & 0.001 \\
\hline Smokers (\%) & $113(35.1)$ & 99 (34.7) & $10(38.5)$ & $4(36.4)$ & 0.93 \\
\hline Energy intake (kcal/day) & $1877 \pm 515$ & $1902 \pm 517$ & $1632 \pm 499$ & $1809 \pm 342$ & 0.03 \\
\hline Total cholesterol (g/l) & $2.24 \pm 0.49$ & $2.28 \pm 0.43$ & $2.04 \pm 0.53$ & $1.74 \pm 0.39$ & 0.0001 \\
\hline HDL cholesterol & $0.51 \pm 0.16$ & $0.51 \pm 0.16$ & $0.49 \pm 0.13$ & $0.48 \pm 0.13$ & 0.59 \\
\hline Prealbuminemia $(\mathrm{mg} / \mathrm{l})$ & $228.1 \pm 54.8$ & $232.4 \pm 51.8$ & $208.1 \pm 62.6$ & $165.6 \pm 67.8$ & 0.0001 \\
\hline $\mathrm{TSH}(\mathrm{mU} / \mathrm{l})$ & $1.29 \pm 0.68$ & $1.27 \pm 0.65$ & $1.40 \pm 0.83$ & $1.62 \pm 0.86$ & 0.16 \\
\hline $\mathrm{FT}_{4}(\mathrm{nmol} / \mathrm{l})$ & $20.24 \pm 3.69$ & $19.90 \pm 3.21$ & $24.74 \pm 4.29$ & $21.63 \pm 6.28$ & 0.0001 \\
\hline $\mathrm{FT}_{3}(\mathrm{nmol} / \mathrm{l})$ & $5.17 \pm 1.00$ & $5.26 \pm 0.92$ & $5.07 \pm 0.97$ & $2.96 \pm 0.41$ & 0.0001 \\
\hline $\mathrm{RT}_{3}(\mathrm{nmol} / \mathrm{l})$ & $0.38 \pm 0.15$ & $0.35 \pm 0.09$ & $0.66 \pm 0.14$ & $0.57 \pm 0.41$ & 0.0001 \\
\hline
\end{tabular}

$\mathrm{BMI}$, body mass index; $\mathrm{HDL}$, high-density lipoprotein; $\mathrm{TSH}$, thyreostimulin hormon; $\mathrm{FT}_{4}$, free $\mathrm{T}_{4} ; \mathrm{FT}_{3}$, free $\mathrm{T}_{3} ; \mathrm{RT}_{3}$, reverse $\mathrm{T}_{3}$. ${ }^{*} P$ value evaluating intergroup comparisons were determined by ANOVA test.

${ }^{\mathrm{a} B o d y}$ mass index was calculated as weight in kilograms divided by height in meters squared. 
Table 2 Characteristics of subjects divided into three tertiles according to reverse triiodothyronine $\left(T_{3}\right)$ level.

\begin{tabular}{|c|c|c|c|c|}
\hline Characteristics & $\begin{array}{l}\text { Lowest tertile } \mathbf{r T}_{3}<\mathbf{0 . 3 1} \\
\qquad(n=104)\end{array}$ & $\begin{array}{l}\text { Middle tertile } \mathbf{r T}_{\mathbf{3}}=\mathbf{0 . 3 1}-\mathbf{0 . 4 1} \\
\qquad(n=109)\end{array}$ & $\begin{array}{l}\text { Highest tertile } \mathbf{r T}_{\mathbf{3}}>\mathbf{0 . 4 1} \\
(n=109)\end{array}$ & $P$ value ${ }^{\star}$ \\
\hline Age (years) & $73.6 \pm 6.2$ & $75.9 \pm 7.3$ & $79.3 \pm 7.5$ & 0.0001 \\
\hline $\operatorname{Sex}(M / F)$ & $53 / 51$ & $61 / 48$ & $54 / 55$ & 0.61 \\
\hline Death (\%) & $65(62.5)$ & $92(84.4)$ & $104(95.4)$ & 0.0001 \\
\hline Median time to death (days) & $4726 \pm 1030$ & $2693 \pm 525$ & $1700 \pm 624$ & 0.0001 \\
\hline BMI $\left(\mathrm{kg} / \mathrm{m}^{2}\right)^{\mathrm{a}}$ & $26.1 \pm 4.7$ & $27.5 \pm 8.3$ & $26.9 \pm 4.4$ & 0.23 \\
\hline Diabetes (\%) & $12(11.5)$ & $11(10.1)$ & $10(9.1)$ & 0.85 \\
\hline Cancer (\%) & $5(4.8)$ & $6(5.5)$ & $4(4.4)$ & 0.80 \\
\hline Cerebrovascular disease & $2(2.1)$ & $9(8.2)$ & $10(9.2)$ & 0.07 \\
\hline Cardiac failure (\%) & $8(7.7)$ & $9(8.2)$ & $16(14.7)$ & 0.18 \\
\hline Ischemic heart disease (\%) & $9(8.7)$ & $13(11.9)$ & $22(20.2)$ & 0.04 \\
\hline Hypertension (\%) & $33(31.7)$ & $39(35.8)$ & $43(39.4)$ & 0.50 \\
\hline Smokers (\%) & 39 (37.5) & $39(36.1)$ & $35(32.1)$ & 0.69 \\
\hline Energy intake (kcal/day) & $2026 \pm 579$ & $1847 \pm 470$ & $1766 \pm 459$ & 0.001 \\
\hline Total cholesterol $(\mathrm{g} / \mathrm{l})$ & $2.32 \pm 0.37$ & $2.25 \pm 0.47$ & $2.14 \pm 0.48$ & 0.02 \\
\hline HDL cholesterol & $0.53 \pm 0.17$ & $0.49 \pm 0.17$ & $0.51 \pm 0.14$ & 0.23 \\
\hline Prealbuminemia (mg/l) & $235.3 \pm 53.8$ & $232.7 \pm 56.8$ & $216.5 \pm 52.4$ & 0.02 \\
\hline TSH $(\mathrm{mU} / \mathrm{l})$ & $1.30 \pm 0.65$ & $1.27 \pm 0.70$ & $1.32 \pm 0.69$ & 0.86 \\
\hline $\mathrm{FT}_{4}(\mathrm{nmol} / \mathrm{l})$ & $18.20 \pm 3.03$ & $20.38 \pm 3.27$ & $22.37 \pm 3.53$ & 0.0001 \\
\hline $\mathrm{FT}_{3}(\mathrm{nmol} / \mathrm{l})$ & $5.19 \pm 0.90$ & $5.31 \pm 1.05$ & $5.00 \pm 1.03$ & 0.08 \\
\hline $\mathrm{RT}_{3}(\mathrm{nmol} / \mathrm{l})$ & $0.25 \pm 0.05$ & $0.36 \pm 0.03$ & $0.53 \pm 0.16$ & 0.0001 \\
\hline
\end{tabular}

BMI, body mass index; $\mathrm{HDL}$, high density lipoprotein; $\mathrm{TSH}$, thyreostimulin hormon; $\mathrm{FT}_{4}$, free $\mathrm{T}_{4} ; \mathrm{FT}_{3}$, free $\mathrm{T}_{3} ; \mathrm{RT}_{3}$, reverse $\mathrm{T}_{3}$. ${ }^{*} P$ value evaluating intergroup comparisons were determined by ANOVA test.

${ }^{\text {aB }}$ ody mass index was calculated as weight in kilograms divided by height in meters squared.

$(P=0.047)$, history of ischemic heart disease $(P=0.01)$, heart failure $(P=0.001)$, and stroke $(P<0.0001)$, low total $(P<0.0001)$ and HDL cholesterol levels $(P=0.02)$, and low prealbuminemia $(P<0.0001)$.

In multivariate analysis (adjusted for age and gender), increased $\mathrm{rT}_{3}(P<0.001)$ and low $\mathrm{FT}_{3}(P<0.001)$ remained associated with shorter survival. This association disappeared for $\mathrm{FT}_{3}(P=0.34)$ after adjustment for other variables associated with early death in a univariate analysis, whereas it remained unchanged for $\mathrm{rT}_{3}(P=0.001$; Table 3, model A). In a full model including $\mathrm{rT}_{3}(P=0.014)$, early death was also significantly related to low caloric intake $(P=0.016)$, low prealbuminemia $(P=0.002)$, decreased total $(P=0.005)$ and HDL cholesterol $(P=0.035)$, and history of ischemic heart disease $(P=0.054)$, stroke $(P=0.037)$, and diabetes $(P=0.019$; Table 3, model $\mathrm{B})$. It is noteworthy that the association between $\mathrm{rT}_{3}$ and survival was stronger after exclusion of participants with low $\mathrm{FT}_{3}$ serum levels $(P<0.0001)$.

To test if the association between $\mathrm{rT}_{3}$ and survival was due to increased short term mortality, subjects who died within 1,2 , and 3 years of inception were subsequently excluded from analysis. The results did not change when subjects who died within 1 or 2 years of inception were excluded $(P=0.003$ and 0.001 respectively in multivariate analysis). Conversely, they were significantly modified after the exclusion of the 71 subjects who died within 3 years of inception since association between survival and baseline $\mathrm{rT}_{3}$ in the remaining subjects completely disappeared in multivariate analysis $(P=0.199)$.

\section{Predictive value of $\mathrm{rT}_{3}$ for mortality}

A ROC curve was created to evaluate the predictive value of $\mathrm{rT}_{3}$ and other variables significantly associated with shorter survival in multivariate analysis (Fig. 2). The area under the curve was the highest for $\mathrm{rT}_{3}$. With the restrictive upper normal value of $0.53 \mathrm{nmol} / \mathrm{l}$ used in our study, its specificity was $98.4 \%$, whereas sensitivity was only $11.5 \%$. The value of $0.38 \mathrm{nmol} / \mathrm{l}$, corresponding to the mean of $\mathrm{rT}_{3}$ in the population gave a specificity of $85.2 \%$ and a sensitivity of $\sim 51 \%$.

\section{Discussion}

In a population of independently-living elderly euthyroid subjects, the Alsanut study demonstrated a significant relationship between $\mathrm{rT}_{3}$ and shorter survival while taking into consideration other critical factors such as age, gender, medical history, nutritional parameters, and energy intake. Conversely, $\mathrm{FT}_{3}, \mathrm{FT}_{4}$, and TSH were not associated with survival in these subjects after adjustment for confounding variables.

Apart from the most severe clinical pictures of hypoand hyperthyroidism, conflicting data exist on whether or not thyroid dysfunction is associated with increased all-causes mortality (14-17). Major methodological differences (populations'age; length in years of followup; co-morbidities considered in the statistical analysis; etc.,) could explain these contradictory results. Similarly, recent meta-analysis did not allow formal conclusion of this possible association $(18,19)$. In our study, their was no significant difference in survival between subjects according to thyroid function. 

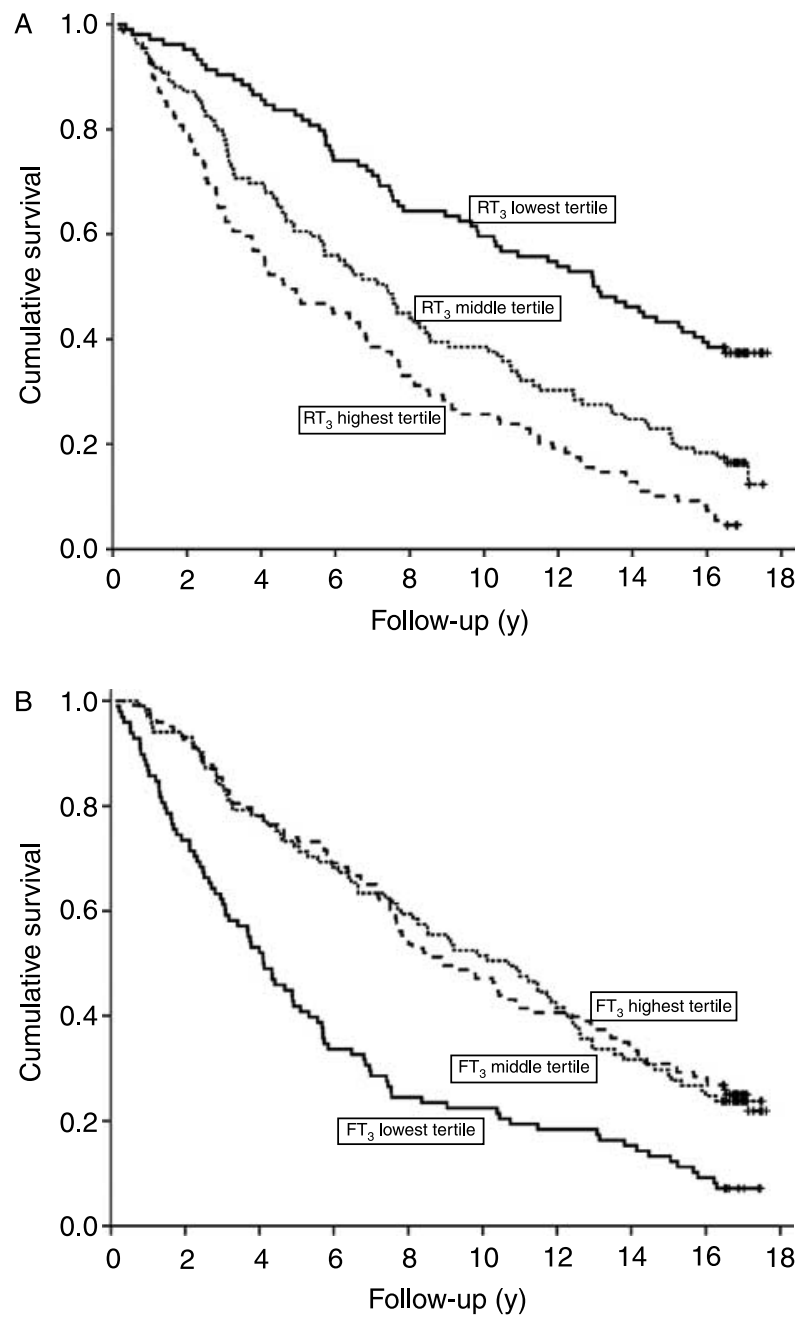

Figure 1 Cumulative survival by tertile of baseline reverse $T_{3}\left(R T_{3}\right)$ (part $A$ ) and free $\left(F_{3}\right)$ (part $B$ ) serum concentrations (Kaplan-Meier analysis). $\mathrm{RT}_{3}$ lowest tertile correspond to serum concentrations lower than $0.31 \mathrm{nmol} / /$, middle tertile to concentrations between 0.31 and $0.41 \mathrm{nmol} / \mathrm{l}$, and the highest tertile concentrations greater than $0.41 \mathrm{nmol} / \mathrm{l}$. $\mathrm{FT}_{3}$ lowest tertile correspond to serum concentrations lower than $3.16 \mathrm{nmol} / /$, middle tertile to concentrations between 3.16 and $4.10 \mathrm{nmol} / \mathrm{l}$, and the highest tertile to concentrations greater than $4.10 \mathrm{nmol} / \mathrm{l}$.

However, the relatively small size of our sample prevents us from adding any reliable proof to this debate.

Conversely, our results concerning the association between survival and $\mathrm{rT}_{3}$ in euthyroid subjects certainly deserve much more attention. $\mathrm{RT}_{3}$ is an isomere of $\mathrm{T}_{3}$ with no demonstrated biological activity. It results from the transformation of $\mathrm{T}_{4}$ through inner ring deiodination by types 1 and 3 deiodinases in peripheral tissue. By contrast outer ring deiodination by types 1 and 2 deiodinases leads to activation of $\mathrm{T}_{4}$ into $\mathrm{T}_{3}(20,21)$. Clinical studies illustrated that $\mathrm{rT}_{3}$ serum concentrations increase with age $(1,12,13)$, the presence of multiple diseases (12), and may be influenced by energy intake (despite conflicting results) $(13,22)$. However, whether these variations should be taken into account is still unknown.

Increased $\mathrm{rT}_{3}$ is usually considered as a part of ESS. This entity is characterized by a constant decrease in $\mathrm{T}_{3}$ serum concentrations, and variable abnormalities of other thyroid hormone levels (4). It is secondary to severe acute (e.g., septic shock, myocardial infarction) $(8,9)$ or chronic (e.g., cancer, advanced acquired immunodeficiency syndrome) (23-25) diseases and it has been demonstrated to be a predictor of increased mortality $(6,18)$. As expected in our population of independently-living non-severely ill people, ESS was rare, occurring in only $3.4 \%$. The one-step method used for $\mathrm{FT}_{3}$ measurement in our study has been criticized because it tends to underestimate $\mathrm{FT}_{3}$ concentrations in ESS, compared with the reference method that is equilibrium dialysis (26). Consequently, the number of participants with ESS might be even lower in our study, and we can be sure that subjects with normal $\mathrm{FT}_{3}$ serum levels did not have ESS.

Despite normal $\mathrm{FT}_{3}, 26$ participants had increased $\mathrm{rT}_{3}$ levels $(>0.53 \mathrm{nmol} / \mathrm{l}$, the upper normal range used in our study), accounting for $8.1 \%$ of the assessable subjects. At baseline, they had older age, lower energy intake, and lower cholesterol levels compared with other participants (13). Similarly, Van den Beld identified more than $25 \%$ of healthy independentlyliving elderly men with a similar hormone profile in a study with a less restrictive upper normal range (12). He showed that these people with isolated increased $\mathrm{rT}_{3}$ had lower physical performance. Thus, in addition to classically defined ESS, elevated $\mathrm{rT}_{3}$ appears far from rare in non-severely ill subjects and seems to be associated with a poor global health status.

In acutely ill patients, $\mathrm{rT}_{3}$ was described as an independent parameter predictive of mortality, as after acute myocardial infarction or in patients hospitalized in intensive care $(8,9)$. In independently-living subjects, mortality data are weak. Only Van den Beld evaluated this parameter in his study and did not find an association between increased $\mathrm{rT}_{3}$ and shorter survival (12). However, he showed an association between low $\mathrm{FT}_{4}$ and 4 year survival. Conversely in our study, $\mathrm{rT}_{3}$ was the only thyroid hormone associated with survival in non-severely ill elderly. With the restrictive upper normal range of $0.53 \mathrm{nmol} / \mathrm{l}$ used in our study, $\mathrm{rT}_{3}$ has a specificity as high as $98.5 \%$ in predicting early death, whereas its sensitivity is quite low at $11.4 \%$.

Our results appear reliable given the quality of the initial selection of subjects, which was carefully done by stratification and randomization in an epidemiological view, giving a perfectly representative sample of the elderly Alsatian population. Additionally, the long follow-up makes it possible to interpret these results over the long term. No definite explanation can be advanced to differentiate our results and Van den Beld's. The main difference between the two populations resides in the fact that he included only men, whereas 
Table 3 Factors associated with all-causes mortality (Cox regression).

\begin{tabular}{|c|c|c|c|c|}
\hline \multirow[b]{2}{*}{ Variable } & \multicolumn{2}{|c|}{ Model A ${ }^{a}$} & \multicolumn{2}{|l|}{ Model B ${ }^{a}$} \\
\hline & Hazard ratio $(95 \% \mathrm{Cl})^{\mathrm{b}}$ & $P$ value & Hazard ratio $(95 \% \mathrm{Cl})^{\mathrm{b}}$ & $P$ value \\
\hline Age (year) & $1.087(1.066-1.109)$ & $<0.001$ & $1.093(1.071-1.115)$ & $<0.001$ \\
\hline $\operatorname{Sex}(M / F)$ & $0.812(0.619-1.065)$ & 0.113 & $0.674(0.504-0.903)$ & 0.008 \\
\hline $\mathrm{RT}_{3}(\mathrm{nmol} / \mathrm{l})$ & $2.858(1.504-5.434)$ & 0.001 & 2.345 (1.185-4.640) & 0.014 \\
\hline Prealbumin (mg/l) & $0.996(0.993-0.999)$ & 0.005 & $0.996(0.993-0.998)$ & 0.002 \\
\hline Total cholesterol (g/l) & $0.598(0.415-0.863)$ & 0.006 & $0.598(0.417-0.858)$ & 0.005 \\
\hline HDL cholesterol (g/l) & $0.348(0.139-0.874)$ & 0.025 & $0.365(0.143-0.930)$ & 0.035 \\
\hline Stroke $(y / n)$ & $1.623(1.023-2.576)$ & 0.040 & $1.641(1.031-2.611)$ & 0.037 \\
\hline Energy intake (kcal/d) & - & - & $1.000(0.999-1.000)$ & 0.016 \\
\hline Ischemic heart disease $(\mathrm{y} / \mathrm{n})$ & - & - & $1.428(0.995-2.050)$ & 0.054 \\
\hline Diabetes (y/n) & - & - & $1.641(1.086-2.481)$ & 0.019 \\
\hline
\end{tabular}

${ }^{a}$ Cox regression model adjusted for age and sex, and stepwise selection among covariates that predicted death in univariate survival analysis $(P<0.10)$ (model A) or stepwise selection among all available covariates (model B).

${ }^{\mathrm{b}} \mathrm{HR}$ for each additional unit increase of the continuous variables or compared with the reference category for dichotomized variables (female sex, no stroke, no ischemic heart disease, no diabetes mellitus).

ours was composed of both genders. Van den Beld's subjects were also probably in better health since none of them were treated for systemic, infectious, inflammatory, or malignant disorders at the time of investigation contrary to ours (13). Otherwise, the mean age of the participants is similar, the size of the two samples is comparable, and the results are based on a single hormone measurement at inclusion in both studies.

Finally, although we suggested previously that $\mathrm{rT}_{3}$ could be a reliable hormonal parameter to appreciate nutritional status (13), we can now propose that elevated $\mathrm{rT}_{3}$ may reflect more than simply the nutritional status but rather a poor overall health status given the relationship between survival and $\mathrm{rT}_{3}$. This is supported by the relation between $\mathrm{rT}_{3}$ and survival resulting from increased short-term mortality, since it disappears after exclusion of the subjects who died within 3 years of inception. We can support Van den Beld's hypothesis that isolated elevated $\mathrm{rT}_{3}$ may be a catabolic state preceding ESS (12). We could also hypothesize that this condition might not be a prestage but rather an equivalent of ESS in the independently-living elderly. Unfortunately, the design of our study does not formally answer this question. A prospective evaluation of subjects with the highest $\mathrm{rT}_{3}$ levels would certainly help to verify whether they develop true ESS throughout standardized biological follow-up and whether death occurs earlier compared with control subjects.

The mechanisms that could explain isolated elevated $\mathrm{rT}_{3}$ remain to be identified. One can hypothesize that they may be at least partly similar to those involved in ESS. These mechanisms remain unclear (reduced activity of type 1 deiodinase $(1,9,21)$, clearance of $T_{3}$ and $\mathrm{rT}_{3}$ by the liver (12), tissular transport of thyroid hormones, nuclear, and post-transcriptional phenomena $(4,27) \ldots)$. Several are in fact probably involved, depending on the underlying disease, and prove that ESS is a heterogenous condition. To explain isolated elevated $\mathrm{rT}_{3}$, it could be hypothesized, for example, that the reduced hepatic clearance of $\mathrm{rT}_{3}$ would appear before, or would be predominant, at this stage on the reduced activity of type 1 deiodinase, which also leads to decreased $\mathrm{FT}_{3}$. Other mechanisms than those leading to non-thyroidal illness are thought to be involved. As previously mentioned, they may be related to age and energy intake which impact on $\mathrm{rT}_{3}$ concentrations. However, according to our results, others are also probably independent of the aging process or nutritional parameters.

Apart from $\mathrm{rT}_{3}$, most other variables associated with survival in our study were previously reported.

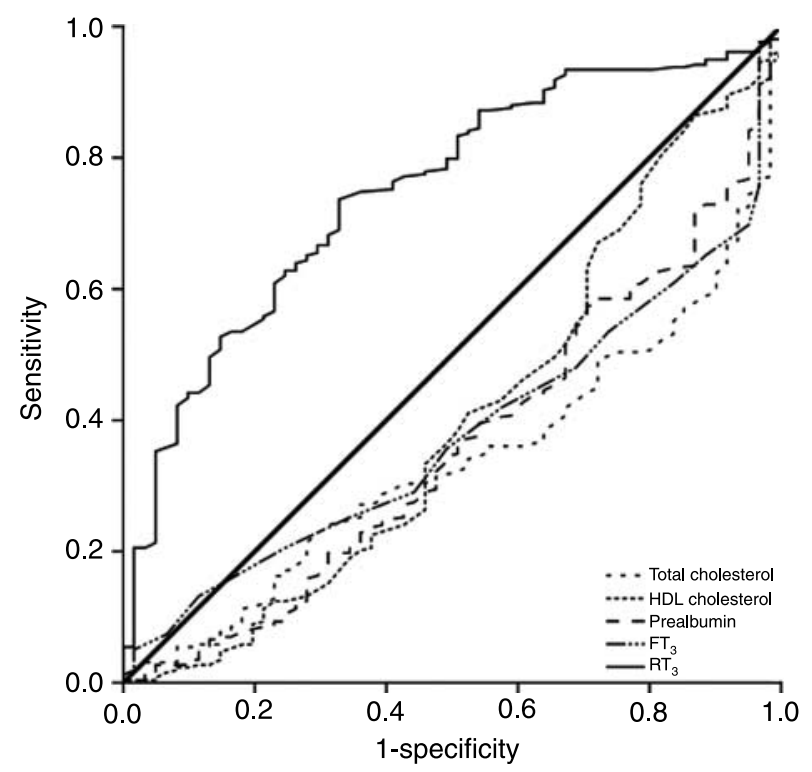

Figure 2 Receiver operating characteristic curves of the biological markers significantly associated with shorter survival in a multivariate analysis. The area under the curve is 0.34 (95\% confidence interval [Cl], 0.27-0.40) for total cholesterol, $0.40(95 \% \mathrm{Cl}, 0.32-$ 0.49 ) for high density lipoprotein (HDL) cholesterol, 0.37 (95\% Cl, 0.29-0.44) for prealbumin, $0.38(95 \% \mathrm{Cl}, 0.31-0.45)$ for free $\mathrm{T}_{3}$ $\left(\mathrm{FT}_{3}\right)$ and $0.75(95 \% \mathrm{Cl}, 0.69-0.81)$ for reverse $\mathrm{T}_{3}\left(\mathrm{RT}_{3}\right)$. 
Nevertheless, the link with nutritional data must be emphasized. Low energy intake, prealbuminemia, and both HDL and total cholesterol were strong predictors of early death in a multivariate analysis including adjustment for BMI. Several authors have published conflicting results on total cholesterol in free-living elderly. Most studies pointed out hypocholesterolemia as an independent predictor of mortality $(28,29)$, whereas others did not (30). Some investigations also underlined the close link between usual nutritional markers such as prealbumin or albumin, cholesterolemia, and health status (31-33). Our study provides additional arguments to these observations. Nevertheless, it should be noted that according to the ROC curve created with our results, $\mathrm{rT}_{3}$ was the best parameter to predict shorter survival among those tested.

In conclusion, our study demonstrates a strong association between $\mathrm{rT}_{3}$ and survival in a population of independently-living elderly subjects regardless of other confounding factors. This 'high $\mathrm{rT}_{3}$ syndrome' might precede an overt 'low $\mathrm{T}_{3}$ syndrome' or might be an equivalent of it in the non-severely ill elderly. Thus, $\mathrm{rT}_{3}$ could deserve to be assessed in elderly subjects with normal TSH. Additional studies are nevertheless necessary to confirm these results and explore the pathophysiological pathways that could lead to elevated $\mathrm{rT}_{3}$.

\section{Declaration of interest}

The authors declare that there is no conflict of interest that could be perceived as prejudicing the impartiality of the research reported. All authors had full access to all of the data in the study and take responsibility for the integrity of the data and the accuracy of the data analysis.

\section{Funding}

This research did not receive any specific grant from any funding agency in the public, commercial, or not-for-profit sector.

\section{Acknowledgements}

We thank Linda Northrup for his help in the preparation of the manuscript.

\section{References}

1 Mariotti S, Franceschi C, Cossarizza A \& Pinchera A. The aging thyroid. Endocrine Reviews 199516 686-715.

2 Chiovato L, Mariotti S \& Pinchera A. Thyroid diseases in the elderly. Bailliere's Clinical Endocrinology and Metabolism 199711 251-270.

3 De Groot LJ. Dangerous dogmas in medicine: the nonthyroidal illness syndrome. Journal of Clinical Endocrinology and Metabolism 199984 151-164.

4 McIver B \& Gorman CA. Euthyroid sick syndrome: an overview. Thyroid 19977 125-132.

5 Maldonado LS, Murata GH, Hershman JM \& Braunstein GD. Do thyroid function tests independently predict survival in the critically ill? Thyroid 19922 119-123.
6 Scoscia E, Baglioni S, Eslami A, Iervasi G, Monti S \& Todisco T. Low triiodothyronine (T3) state: a predictor of outcome in respiratory failure? Results of a clinical pilot study European Journal of Endocrinology $2004151557-560$.

7 Plikat K, Langgartner J, Buettner R, Bollheimer LC, Woenckhaus U, Schölmerich J \& Wrede CE. Frequency and outcome of patients with nonthyroidal illness syndrome in a medical intensive care unit. Metabolism 200756 239-244.

8 Friberg L, Drvota V, Bjelak AH, Eggertsen G \& Ahnve S. Association between increased levels of reverse triiodothyronine and mortality after acute myocardial infarction. American Journal of Medicine 2001111 699-703.

9 Peeters RP, Wouters PJ, van Toor H, Kaptein E, Visser TJ \& Van den

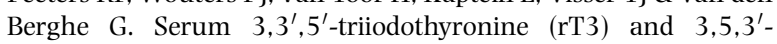
triiodothyronine/rT3 are prognostic markers in critically ill patients and are associated with postmortem tissue deiodinase activities. Journal of Clinical Endocrinology and Metabolism 200590 4559-4565.

10 Iervasi G, Pingitore A, Landi P, Raciti M, Ripoli A, Scarlattini M, L'Abbate A \& Donato L. Low-T3 syndrome: a strong prognostic predictor of death in patients with heart disease. Circulation 2003 107 708-713.

11 Mariotti S, Barbesino G, Caturegli P, Bartanela L, Sansoni P, Fagnoni F, Monti D, Fagiolo U, Franceschi C \& Pinchera A. Complex alteration of thyroid function in healthy centenarians. Journal of Clinical Endocrinology and Metabolism $1993 \quad \mathbf{7 7}$ 1130-1134.

12 van den Beld AW, Visser TJ, Feelders RA, Grobbee DE \& Lamberts SW. Thyroid hormone concentrations, disease, physical function, and mortality in elderly men. Journal of Clinical Endocrinology and Metabolism 200590 6403-6409.

13 Goichot B, Schlienger JL, Grunenberger F, Pradignac A \& Sapin R. Thyroid hormone status and nutrient intake in the free-living elderly. Interest of reverse triiodothyronine assessment. European Journal of Endocrinology 1994130 244-252.

14 Parle JV, Maisonneuve P, Sheppard MC, Boyle P \& Franklyn JA. Prediction of all-cause and cardiovascular mortality in elderly people from one low serum thyrotropin result: a 10-year cohort study. Lancet 2001358 861-865.

15 Gussekloo J, van Exel E, de Craen AJ, Meinders AE, Frolich M \& Westendorp RG. Thyroid status, disability and cognitive function, and survival in old age. Journal of the American Medical Association 2004292 2591-2599.

16 Walsh JP, Bremner AP, Bulsara MK, O'Leary P, Leedman PJ, Feddema P \& Michelangeli V. Subclinical thyroid dysfunction as a risk factor for cardiovascular disease. Archives of Internal Medicine 2005165 2467-2472.

17 Cappola AR, Fried LP, Arnold AM, Danese MD, Kuller LH, Burke GL, Tracy RP \& Ladenson PW. Thyroid status, cardiovascular risk, and mortality in older adults. Journal of the American Medical Association 2006295 1033-1041.

18 Volzke H, Schwahn C, Wallaschofski H \& Dorr M. The association of thyroid dysfunction with all-cause and circulatory mortality: is there a causal relationship? Journal of Clinical Endocrinology and Metabolism 200792 2421-2429.

19 Haentjens P, Van Meerhaeghe A, Poppe K \& Velkeniers B. Subclinical thyroid dysfunction and mortality: an estimate of relative and absolute excess all-cause mortality based on timeto-event data from cohort studies. European Journal of Endocrinology 2008159 329-341.

20 Moreno M, Berry MJ, Horst C, Thoma R, Goglia F, Harney JW, Larsen PR \& Visser TJ. Activation and inactivation of thyroid hormone by type I iodothyronine deiodinase. FEBS Letters 1994 344 143-146.

21 Bianco AC, Salvatore D, Gereben B, Berry MJ \& Larsen PR. Biochemistry, cellular and molecular biology, and physiological roles of the iodothyronine selenodeiodinases. Endocrine Reviews 200223 38-89. 
22 Fontana L, Klein S, Holloszy JO \& Premachandra BN. Effect of longterm calorie restriction with adequate protein and micronutrients on thyroid hormones. Journal of Clinical Endocrinology and Metabolism $2006913232-3235$.

23 Hoffmann CJ \& Brown TT. Thyroid function abnormalities in HIVinfected patients. Clinical Infectious Diseases 200745 488-494.

24 Cengiz SE, Cetinkaya E, Altin S, Gunluoglu Z, Demir A, Gunluoglu G \& Epozturk K. Nutritional and prognostic significance of sick euthyroid syndrome in non-small cell lung cancer patients. Internal Medicine 200847 211-216.

25 Vexiau P, Perez-Castiglioni P, Socie G, Devergie A, Toubert ME, Aractingi S \& Gluckman E. The 'euthyroid sick syndrome': incidence, risk factors and prognostic value soon after allogeneic bone marrow transplantation. British Journal of Haematology 1993 85 778-782.

26 Sapin R, Schlienger JL, Kaltenbach G, Gasser F, Christofides N, Roul G, Gervais A, Petitjean P \& Chambron J. Determination of free triiodothyronine by six different methods in patients with nonthyroidal illness and in patients treated with amiodarone. Annals of Clinical Biochemistry 199532 314-324.

27 Papanicolaou DA. Euthyroid sick syndrome and the role of cytokines. Reviews in Endocrine and Metabolic Disorders 20001 $43-48$.

28 Rozzini R, Sabatini T, Franzoni S \& Trabucchi M. Cholesterol and mortality in elderly patients. Journal of the American Geriatrics Society 200452 469-470.
29 Schupf N, Costa R, Luchsinger J, Tang MX, Lee JH \& Mayeux R. Relationship between plasma lipids and all-cause mortality in nondemented elderly. Journal of the American Geriatrics Society $200553219-226$.

$30 \mathrm{Hu}$ P, Seeman TE, Harris TB \& Reuben DB. Does inflammation or undernutrition explain the low cholesterol-mortality association in high-functioning older persons? MacArthur studies of successful aging Journal of the American Geriatrics Society 200351 80-84.

31 Volpato S, Leveille SG, Corti MC, Harris TB \& Guralnik JM. The value of serum albumin and high-density lipoprotein cholesterol in defining mortality risk in older persons with low serum cholesterol. Journal of the American Geriatrics Society 200149 1142-1147.

32 Goichot B, Schlienger JL, Grunenberger F, Pradignac A \& Aby MA. Low cholesterol concentrations in free-living elderly subjects: relations with dietary intake and nutritional status. American Journal of Clinical Nutrition 199562 547-553.

33 Reuben DB, Ix JH, Greendale GA \& Seeman TE. The predictive value of combined hypoalbuminemia and hypocholesterolemia in high functioning community-dwelling older persons: MacArthur studies of successful aging. Journal of the American Geriatrics Society $199947402-406$.

Received 15 October 2008

Accepted 9 November 2008 